3. Куратченко М.В. Особливості взаємодії слідчих та оперативних підрозділів при розслідуванні сутенерства та втягнення особи в заняття проституцією. Науковий вісник Дніпропетровського держ. ун-ту внутрішніх справ : збірник наук. праць. 2017. № 2. С. 227-234.

4. Лазарев В.А. Типичные следственные ситуации расследования вовлечения несовершеннолетнего в занятие проституции и сутенерстве. Международный научно-практический журнал «Право и Закон». 2017. № 3. С. 107-112.

5. Малярова В.О. Тактико-криміналістичні та процесуальні основи пошуку та затримання злочинця : дис. ... канд. юрид. наук : 12.00.09 / Нац. ун-т внутр. справ. Харків, 2005. 238 с.

6. Назаренко К.Ю. Методика розслідування злочинів, пов'язаних зі створенням або утриманням місць розпусти і звідництвом : монографія / Дніпро : Дніпроп. держ. ун-т внутр. справ; Ліра ЛТД, 2017. 190 c.

7. Справа № 361/3876/17, Архів Броварського міськрайонного суду Київської обл., 2017 р.

8. Справа № 522/13846/15-к, Архів Приморського районного суду м. Одеси, 2015 р.

9. Цыркун С.А. Выявление и расследование преступлений, связанных с содержанием притонов для занятия проституцией : автореф. дис. ... канд. юрид. наук. Москва : Московская государственная юридическая академия, 2004. $21 \mathrm{c.}$

УДК $343.98: 343.131$

DOI https://doi.org/10.32844/2618-1258.2019.5-1.41

ЄФІМОВ М.М.

\title{
ДЕЯКІ АСПЕКТИ ПІЗНАВАЛЬНОЇ ДІЯЛЬНОСТІ СЛІДЧОГО, ЩО ВИКЛИКАЮТЬ СУМНІВИ СТОСОВНО ОСУДНОСТІ ОСОБИ ПІД ЧАС РОЗСЛІДУВАННЯ ЗЛОЧИНІВ ПРОТИ МОРАЛЬНОСТІ
}

Наукова стаття присвячена висвітленню деяких аспектів розслідування злочинів проти моральності. Досліджено деякі аспекти пізнавальної діяльності слідчого, під час якої виникають сумніви щодо осудності особи, яка вчинила кримінальне правопорушення. Доведено, що сумнів щодо осудності особи виникає не лише внаслідок отримання документів про наявність в особи психічного захворювання, а також під час безпосереднього спостерігання слідчим емоційного стану особи, ії способу мислення, рівня розвитку інтелекту, пам'яті, мовлення.

Встановлено, що питання щодо визначення віку особи, а також первісної кваліфікації злочинних діянь на початку досудового розслідування, як правило, не викликають у слідчих складнощів, то встановлення осудності особи потребує спеціальних знань та практичних навичок. 3'ясовано, що пізнавальна діяльність слідчого у процесі розслідування злочинів проти моральності здебільшого досліджується науковцями з позиції змоги побудувати версії злочину, встановити зв'язки між окремими фактами події з метою підтвердити чи, навпаки, спростувати ці версії, встановити особу винного, а сама особа винного досліджується через вивчення iіi способу життя. Але, на нашу думку, слідчий має змогу і повинен використовувати такий пізнавальний інструмент, як власне спостереження за поведінкою особи, включаючи ії темперамент, спосіб мислення, рівень інтелекту тощо.

Наголошується на тому, що емоційний стан підозрюваного, порушення пам'яті та інтелекту, дефекти мовлення підозрюваного, що виявляються під час проведення з ним слідчих (розшукових) дій при розслідуванні злочинів проти моральності, мають сприйматися слідчим у взаємозв'язку, взаємозумовленості та оцінюватися не лише з точки зору лінії захисту підозрюваного, а також ознак, що можуть вказувати на психічні розлади особи. Поряд з іншими добутими під час досудового

ЄФІМОВ М.М. - кандидат юридичних наук, доцент, доцент кафедри криміналістики, судової медицини та психіатрії (Дніпропетровський державний університет внутрішніх справ) 
розслідування доказами власні спостереження слідчого сприятимуть прийняттю рішення про залучення спеціаліста до тієї чи іншої слідчої (розшукової) дії або проведення судово-психіатричної експертизи з метою вирішення питання про наявність в особи психічного захворювання, тимчасового розладу психічної діяльності, недоумства або іншого хворобливого стану психіки на момент вчинення нею кримінального правопорушення.

Ключові слова: неосудність, осудність, пізнавальна діяльність слідчого, примусові заходи медччного характеру, злочини проти моральності, слідчі (розщукові) diï.

The scientific article deals with some aspects of the investigation of crimes against morality. Some aspects of cognitive activity of investigator, during that there are doubts in relation to responsibility of person, that accomplished criminal offence, are investigational. It is well-proven that a doubt in relation to responsibility of person arises up not only as a result of receipt of documents about a presence in the persons of psychical disease, and also during a direct supervision to the investigators of the emotional state of person, his way of thinking, level of development of intellect, memory, broadcasting.

It is set that a question is in relation to determination of age of person, and also primitive qualification of criminal acts at the beginning of pre-trial investigation as a rule is not caused at inquisitional complications, then establishment of responsibility of person needs the special knowledge and practical skills. It is found out, that cognitive activity of investigator at investigation of crimes against morality mostly investigated by scientists from position of possibilities to build the versions of crime, set copulas between the separate facts of event with the purpose of confirmation or vice versa refute these versions, set a person guilty, and self person guilty investigated through the study of her way of life. But, to our opinion, an investigator has the opportunity and must use such cognitive instrument, as an own watching behavior of person, including her temperament, way of thinking, level of intellect and others like that.

It is marked on that the emotional state of suspected, violation of memory and intellect, defects of broadcasting suspected, that appear during realization with him of inquisitional (of criminal investigation) actions at investigation of crimes against morality, must be perceived to the investigators in intercommunication, to the interconditionality and estimated not only from the point of view of line of defence suspected, and also signs that can specify on the psychonosemas of person. Next to other proofs obtained during pre-trial investigation the own supervisions of investigator will assist a decision-making about bringing in of specialist to the other investigative (search) actions.

Key words: diminished responsibility, responsibility, cognitive activity of investigator, force events of medical character, crimes against morality, investigative (search) actions.

Вступ. Суб’єктом кримінального правопорушення є фізична осудна особа, яка вчинила злочин у віці, з якого відповідно до Кримінального кодексу України (далі - КК) може наступати кримінальна відповідальність. Якщо питання щодо визначення віку особи, а також первісної кваліфікації злочинних діянь на початку досудового розслідування, як правило, не викликають у слідчих складнощів, то встановлення осудності особи потребує спеціальних знань та практичних навичок. Тому виникає потреба у проведенні дослідження деяких аспектів кримінальної процесуальної діяльності слідчого, пов'язаної з виникненням сумнівів щодо осудності особи, яка вчинила кримінальне правопорушення проти моральності.

Кримінальну процесуальну діяльність слідчого в різних іï аспектах досліджували сучасні науковці: І.В. Басиста, В.І. Брездень, В.В. Вапнарчук, В.М. Галунько, В.Я. Горбачевський, В.А. Журавель, О.С. Звірко, В.В. Король, В.В. Тіщенко, І.М. Охріменко, О.О. Толкаченко, К.О. Чаплинський, О.М. Цільмах, М.С. Цуцкірідзе та інші. Проте в їх роботах розглядаються загальні питання організації досудового розслідування, та вони не торкаються особливих порядків, зокрема кримінального провадження щодо застосування примусових заходів медичного характеру (далі - ПЗМХ). Загалом кримінальна процесуальна діяльність слідчого у кримінальному провадженні щодо застосування ПЗМХ є малодослідженою, хоча не випадає з поля зору науковців. 
Так, В.Г. Дрозд розглядав питання про звернення до суду з клопотанням про застосування ПЗМХ. Також є дослідження Н.М. Сенченко, В.Ф. Гаєвого, О.В. Крикунова про здійснення кримінального провадження щодо застосування ПЗМХ.

Постановка завдання. Метою статті є дослідження кримінальної процесуальної діяльності слідчого як пізнавальної діяльності, під час якої може виникнуть сумнів щодо осудності особи, яка вчинила кримінальне правопорушення проти моральності.

Результати дослідження. За сучасним кримінальним концептом, неосудність є обставиною, що виключає кримінальну відповідальність особи, а обмежена осудність - обставиною, яка може привести до відтермінування притягнення особи до кримінальної відповідальності, оскільки може бути підставою для застосування до неї ПЗМХ. В.М. Бурдін зазначає, що вирішення питання про осудність чи неосудність особи має відбуватися на момент вчинення суспільно небезпечного діяння, передбаченого КК України [1, с. 92-93]. Тому незалежно від того, скільки часу сплинуло після вчинення злочинної події, перед слідчим постає питання визначення осудності особи саме на момент вчинення кримінального правопорушення.

За ч. 1 ст. 19 КК, осудною визнається особа, яка під час вчинення злочину могла усвідомлювати свої дії (бездіяльність) і керувати ними [5]. Отже, неосудною є особа, яка не могла усвідомлювати свої дії (бездіяльність) або керувати ними під час вчинення суспільно небезпечного діяння, а обмежено осудною визнається особа, яка вчинила злочин у стані осудності, але до постановлення вироку захворіла на хворобу, яка позбавляє іії змоги усвідомлювати свої дії (бездіяльність) або керувати ними. При цьому втрата емоційно-вольового контролю особи пов'язана з наявністю в неї хронічного психічного захворювання, тимчасового розладу психічної діяльності, недоумства або іншого хворобливого стану психіки.

За інформацією прес-служби Міністерства охорони здоров'я станом на 2017 р. в Україні щонайменше 1,7 млн українців потребували психіатричної та наркологічної допомоги, а за даними Всесвітньої організації охорони здоров'я, якщо показник глобального тягаря захворювань для психічних розладів у 2004 р. становив $13 \%$, то в 2020 р. сягне $15 \%$. При цьому найвищим цей показник є для країн Східної Європи, до яких належить і Україна [2]. Разом з тим в Україні діє принцип презумпції психічного здоров'я, відповідно до якого кожна особа вважається такою, яка не має психічного розладу, доки наявність такого розладу не буде встановлена на підставах та в порядку, передбачених законами України [9]. Отже, осудність особи може бути поставлена під сумнів лише тоді, коли є об'єктивні обставини, які дають підстави вважати, що під час вчинення суспільно небезпечного діяння особа була в неосудному або обмежено осудному стані або вчинила кримінальне правопорушення в осудному стані, але після його вчинення захворіла на психічну хворобу.

За визначенням, наданим у філософському енциклопедичному словнику, сумнів - це особливий стан свідомості і самосвідомості, коли суб'єкт відчуває або виявляє недовіру до певного твердження, вагаючись щодо прийняття (визнання) його, оскільки оцінює це твердження як недостатньо обгрунтоване, правомірне, виправдане, необхідне, переконливе [11, с. 615-616]. В.Ю. Шепітько виділяє два види взаємодії між особами й об'єктами, під час яких здійснюється пізнавальна діяльність слідчого: 1) між слідчим і особою, яка вчинила злочинне діяння (чи іншою особою); 2) слідчим і речами (носіями матеріальних відображень про злочин і його учасників $[14$, с. $87-88]$.

О.М. Цільмак зазначає, що під час здійснення професійних функцій слідчий отримує вихідну інформацію у вигляді конкретних чуттєвих образів, що виникають під час слідчих дій (обшуку, огляду місця події, слідчого експерименту тощо), вислуховування свідчень, наданих усно, та читання свідчень, наданих письмово, у вигляді документів, протоколів, довідок тощо [12, с. 336]. Отже, сумнів слідчого стосовно осудності особи, що вчинила кримінальне правопорушення, може виникнути не лише під час допиту підозрюваного, свідків, а також таких слідчих (розшукових) дій, як слідчий експеримент, обшук, огляд місцевості, приміщення, документів тощо.

Так, маркером для зародження в слідчого сумнівів стосовно осудності особи $є$ характеристика місця, часу і предмета вчинення кримінального правопорушення. К.О. Чаплинський зазначає, що така слідча дія, як огляд дає змогу слідчому скласти уявлення про механізм злочину та особу злочинця [13, с. 14]. На думку С.М. Лозової, про психічні особливості особи, що вчинила суспільно небезпечне діяння, можуть свідчити явна алогічність поведінки на місці події, особлива жорстокість відносно жертви, вияви садизму, сексуальної патології, алогічність пошкоджень обстановки, деякі інші сліди аномальної активності, що виявляються ззовні [6, с. 108]. 
Наприклад, 3 архівних матеріалів кримінальної справи № 415/1943/13-к, провадження № 1-КП/415/166/13, в якій Лисичанським міським судом Луганської області 11 квітня 2013 р. постановлена ухвала про застосування до особи ПЗМХ, видається, що після спричинення ножем батькові тілесних ушкоджень він ліг у ліжко [8]. Деснянським районним судом м. Чернігова під час розгляду кримінальної справи № 2506/11904/2012, провадження № 1-кп/750/16/2013, встановлено, що особа, здійснивши в голову потерпілому шість пострілів, бачачи, що «його голова та обличчя були в крові, його ноги та руки смикались», забрала пістолет та курточку, замкнула двері на ключ та пішла додому [7]. Ось така байдужість особи до потерпілого, що може сприйматися як прямий умисел на вбивство, має викликати питання в слідчого щодо психічного стану особи, бо вона виявляє одночасно й байдужість до власного майбутнього, життя, в її поведінці після вчинення тяжкого правопорушення не простежується інстинкт самозбереження, який, як правило, змушує злочинця зникнути з місця події, максимально прибрати сліди, що можуть вказувати саме на нього як підозрюваного у вчиненому діянні, створити собі алібі тощо.

Втім, необхідно також пам'ятати, що такі типові ознаки, як невиправданий безлад на місці події, наявність зайвих, нічим не пояснених чисельних пошкоджень учинення злочину та інші, можуть також вказувати на інсценування злочину, тобто штучне створення зацікавленими особами обстановки, яка б утворювала помилкове уявлення про нібито учинене кримінальне правопорушення [4, с. 261-262]. Уникнути похибки в таких випадках дають змогу системний підхід до аналізу обстановки кримінального правопорушення, проведення допитів, експертиз, слідчих експериментів тощо.

Зрозуміло, що основний обсяг інформації, необхідної для ствердження або спростування осудності підозрюваного, слідчий може отримати під час допиту, що являє собою регламентований кримінально-процесуальними нормами інформаційно-психологічний процес спілкування осіб із метою отримання показань про подію, яка стала предметом кримінального провадження [3, с. 248]. Унаслідок уміло проведеного допиту у свідомості слідчого має утворитися не лише об'єктивна картина події злочину, а також скластися уявлення про індивідуальні психофізичні властивості підозрюваного, що становлять основу його відчуттів і сприйняття, мислення, пам'яті, емоційних переживань тощо.

Так, під час допиту підозрюваний Г. щодо вчиненого ним кримінального правопорушення пояснив, що за кілька днів до того почав помічати, що люди, які його оточують, «якось змінилися», програми у телевізорі перемикалися самі, бачив через телевізор, як кружляли інопланетяни, бо «місто захопити хотіли», вважав, що батька підмінили, - «він перестав помічати очевидні речі»; за тиждень до арешту в нього знизився настрій, з'явилася тривога, він був напружений; ввечері був у кафе, прийшов випити кави; вважає, що отруївся, оскільки одразу після вживання з'явилась блювота - «рвав біля кафе, потім вдома»; почував себе погано, всю ніч не спав, думав про батька - «подумав, що він безсмертний, йому ввели транквілізатор, хотів перевірити, помре він чи ні, думав, що його заберуть інопланетяни»; вранці прийшов до кухні, побачив батька, той здався йому «іншим, як інопланетянин; взяв ножа і завдав йому удар в спину; коли побачив кров, звернув увагу, що вона була незвичайною, - «якась розова, як марганець, не така, як у людей» [8]. Отже, вчиненню особою суспільно небезпечного діяння передували емоційні переживання, пов'язані із зоровими галюцинаціями, тобто уявними сприйняттями зорових образів без реального нині подразника.

Пізнавальна діяльність слідчого при розслідуванні злочинів проти моральності здебільшого досліджується науковцями з позиції можливостей побудувати версії злочину, встановити зв'язки між окремими фактами події з метою підтвердити чи, навпаки, спростувати ці версії, встановити особу винного, а сама особа винного досліджується через вивчення її способу життя. Але, на нашу думку, слідчий має змогу і має використовувати такий пізнавальний інструмент, як власне спостереження за поведінкою особи, включаючи ії темперамент, спосіб мислення, рівень інтелекту тощо.

Під мисленням розуміють інформаційну діяльність, що набула якості опосередкованого, узагальненого пізнання, яке за допомогою абстрагування, міркувань (зіставлень пізнавальних образів та логічного виведення думок) і типізації даних про світ явищ розкриває їх необхідні зв'язки, закономірності, тенденції розвитку [11, с. 378]. Мислення здійснюється у формі судження, що розкривається через побудову умовиводів. Основу судження становлять поняття про світ, а формою передачі суджень виступає знакова система, що називається мовою. Отже, мислення реалізується через мовлення, яке існує у формі зовнішнього (усного, письмового) мислення та внутрішнього («про себе») мислення. Класифікація порушень мислення складається з чоти- 
рьох основних розділів: 1) порушення утворень понять; 2) порушення темпу мислення; 3) порушення форми мислення; 4) порушення змісту мислення [10, с. 65-66]. Отже, застосування підозрюваними неологізмів, прискорене або, навпаки, уповільнене мислення, затримка мислення або наплив думок, патологічна докладність мислення, резонерство, паралогічність мислення, зісковзування з думок, розірваність та незв'язність мислення, що можуть безпосередньо сприйматися слідчим під час допиту, мають викликати в нього сумніви щодо здатності особи правильно сприймати себе, навколишній світ та керувати своїми діями.

Так само й емоційний стан підозрюваного, порушення пам'яті та інтелекту, дефекти мовлення підозрюваного, що виявляються під час проведення з ним слідчих (розшукових) дій у процесі розслідування злочинів проти моральності, мають сприйматися слідчим у взаємозв'язку, взаємозумовленості та оцінюватися не лише з точки зору лінії захисту підозрюваного, а також ознак, що можуть вказувати на психічні розлади особи. Поряд з іншими добутими під час досудового розслідування доказами власні спостереження слідчого сприятимуть прийняттю рішення про залучення спеціаліста до тієї чи іншої слідчої (розшукової) дії або проведення судово-психіатричної експертизи з метою вирішення питання про наявність в особи психічного захворювання, тимчасового розладу психічної діяльності, недоумства або іншого хворобливого стану психіки на момент вчинення нею кримінального правопорушення.

Висновки. Підсумовуючи, зазначимо, що призначенню судово-психіатричної експертизи підозрюваного у процесі розслідування злочинів проти моральності передує пізнавальна діяльність слідчого під час проведення ним слідчих (розшукових) дій (огляд місцевості, допит підозрюваного та свідків, огляд трупа, слідчий експеримент, обшук тощо), що пов'язана з оцінкою емоційного стану підозрюваного, способом його мислення, розвитком інтелекту, пам'яті та викликає реальний сумнів щодо осудності цієї особи.

\section{Список використаних джерел:}

1. Бурдін В.М. До питання про часові межі осудності. Бюлетень Міністерства юстиції України. 2007. № 2. С. 83-94.

2. URL: https://tsn.ua/ukrayina/mayzhe-2-milyoni-ukrayinciv-potrebuyut-psihiatrichnoyi-tanarkologichnoyi-dopomogi-moz-921697.html?utm source=page\&utm medium=readmore

3. Єфімов М.М. Деякі аспекти допиту різних категорій осіб при розслідуванні злочинів проти моральності. Науковий вісник ДДУВС. 2017. № 4. С. 246-253.

4. Криміналістика : підручник / К.О. Чаплинський, О.В. Лускатов, І.В. Пиріг, В.М. Плетенець, Ю.А. Чаплинська. 2-ге вид. перероб. і доп. Дніпро : Ліра ЛТД, 2017. 480 с.

5. Кримінальний кодекс України від 05.04.2001 p. № 2341-III. URL: https://zakon.rada.gov.ua/ laws/card/2341-14.

6. Лозова С.М. Особливості розслідування суспільно небезпечних діянь, учинених особами з психічними захворюваннями або тимчасовими розладами психіки. Теорія та практика судової експертизи і криміналістики : збірник наук. праць. Харків : Право, 2014. Вип. 14. C. 106-112.

7. Матеріали кримінального провадження № 2506/11904/2012, № 1-кп/750/16/2013. Архів Деснянського районного судум. Чернігова.

8. Матеріали кримінального провадження № 415/1943/13-к, № 1-КП/415/166/13 від 15.03.2013 р. Архів Лисичанського міського суду Луганської області.

9. Про психіатричну допомогу : Закон України від 22.02 .2000 p. № 1489-III. URL: http://zakon5.rada.gov.ua/laws/show/1489-14/page2.

10. Психіатрія і наркологія : підручник / В.Л. Гавенко та ін.; за заг. ред. В.Л. Гавенка, В.С. Бітенського. 2-ге вид., перероб. і доповн. Київ : ВСВ «Медицина», 2015. 512 с.

11. Філософський енциклопедичний словник / під ред. проф. В.І. Шинкаренка. Київ : Абрис, 2002. $751 \mathrm{c}$.

12. Цільмак О.М. Психологічна структура слідчої діяльності. Науковий вісник Львівського держсавного ун-ту внутрішніх справ. 2012. № 2(1). С. 330-337.

13. Чаплинський К.О. Тактика проведення окремих слідчих дій : монографія. Дніпропетровськ, 2006. $416 \mathrm{c}$.

14. Шепітько В.Ю. Криміналістична тактика (системно-структурний аналіз) : монографія. Харків : Харків юрид., 2007. 432 с. 